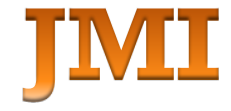

\title{
Kointegrasi dan Kausalitas Bitcoin terhadap Nilai Tukar Rupiah: Pandangan Islam
}

\author{
Dewi Jumiarti ${ }^{1}$, Hayet $^{2}$ \\ ${ }^{1}$ Prodi Ekonomi Islam, Fakultas Ekonomi dan Bisnis, Untan, INDONESIA, email: \\ dewijumiarti6@gmail.com \\ 22Fakultas Ekonomi dan Bisnis, Untan, INDONESIA, email: hayet_rakhi@gmail.com
}

\begin{abstract}
ABSTRAK
Tujuan penelitian untuk mengetahui kointegrasi, kausalitas berikut pengaruh antara Bitcoin dan nilai tukar Rupiah. Metode penelitian uji regresi linier sederhana dengan metode ARCHGARCH, Kointegrasi Johansen, dan Kausalitas Engel Granger. Data Bitcoin dan nilai tukar menggunakan data mingguan selama enam tahun (2013-2019). Penelitian ini mendapatkan Bitcoin tidak memiliki kointegrasi jangka panjang dengan nilai tukar Rupiah. Hubungan kausalitas berbentuk pola satu arah yang terjadi pada Bitcoin terhadap nilai tukar Rupiah. Bitcoin memiliki pengaruh positif terhadap nilai tukar Rupiah. Transaksi Bitcoin tidak memenuhi salah satu rukun maupun syarat dalam al-sharf sehingga tidak sesuai dengan ketentuan syariat Islam serta transaksi tidak dapat dibatalkan walaupun terjadi pending order. Bitcoin lebih beresiko pada maysir, batil, dan gharar.
\end{abstract}

Kata Kunci: Bitcoin, Rupiah, Nilai Tukar, Al-sharf. 


\section{PENDAHULUAN}

Perkembangan teknologi dalam bidang ekonomi mengalami kemajuan yang sangat pesat. Salah satunya transaksi sistem pembayaran non-tunai. Terciptalah Bitcoin sebagai sistem digital mata uang hasil perpaduan kode rahasia (kriptografi) sehingga terbentuk keamanan transaksi yang dianggap sebagai ayah dari cryptocurrency (Sovbetov, 2018). Saat ini cryptocurrency yang pertama dan paling popular ditransaksikan yaitu Bitcoin (Coinmarket, 2019). Ketertarikan isu Bitcoin menduduki urutan pertama dominasi cryptocurrency dengan penguasaan 49\% kapitalisasi pasar, cryptocurrency dianggap mampu menyaingi mata uang konvensional dengan kelemahan tingginya biaya transaksi, kurangnya efisiensi sehingga berdampak kepada pihak-pihak yang terlibat pada sistem Bitcoin, seperti yang dikatakan (Kien, 2014) yaitu: bisnis pertukaran, penambang, pengguna, penerima pembayaran dengan bitcoin, bitcoin yang dibeli dan dijual. Pergerakan dan pertukaran yang cenderung fluktuatif pada Bitcoin dan nilai tukar Rupiah memberikan gambaran menariknya pembahasan hubungan yang terjadi antara Bitcoin serta nilai tukar Rupiah ketika Bitcoin mengalami pergerakan meningkat terjadi sebaliknya pada nilai tukar Rupiah yang menunjukkan pergerakan melemah sehingga terjadi perbedaan yang signifikan.

Pertukaran mata uang atau kurs, harus memenuhi syarat-syarat yang telah ditetapkan sebagaimana hadis atau dalil kebolehan pertukaran tersebut adalah: "Juallah emas dengan perak sesuka kalian, dengan (syarat harus) kontan." (Hr. Imam At-Tirmidzi, dari Ubadah bin Shamit). Firman Allah dalam QS. Al A'raf ayat 85 menjelaskan:

Artinya: "Dan (Kami telah mengutus) kepada penduduk Mad-yan saudara mereka, Syu'aib. Ia berkata: "Hai kaumku, sembahlah Allah, sekali-kali tidak ada Tuhan bagimu selain-Nya. Sesungguhnya telah datang kepada mu bukti yang nyata dari Tuhanmu. Maka sempurnakanlah takaran dan timbangan dan janganlah kamu kurangkan bagi manusia barang-barang takaran dan timbangannya, dan janganlah kamu membuat kerusakan di muka bumi sesudah Tuhan memperbaikinya. Yang demikian itu lebih baik bagimu jika betul-betul kamu orang-orang yang beriman."

Nilai tukar suatu negara merupakan satu indikator untuk melihat stabilitas perekonomian suatu negara. Semakin stabil nilai tukar mata uang suatu negara terhadap negara lain menunjukkan bahwa satu mata uang suatu negara dapat membeli lebih banyak mata uang negara lain, sehingga produk asing lebih murah bagi pembeli domestik akhirnya mendorong pengiriman impor dan sebaliknya (Ramadhani, 2015). Apabila membahas Bitcoin sebagai mata uang fiat dibahas dengan Fatwa Dewan Syari'ah Nasional mengenai jual beli mata uang (al-Sharf) yang menerangkan bahwa transaksi mata uang yang diperbolehkan dalam islam, harus sesuai dengan ketentuan syariat yaitu tidak untuk spekulasi, adanya kebutuhan transaksi, dilakukan terhadap mata uang sejenis maka nilainya harus sama, tunai (attaqabudh), apabila berlainan maka dilakukan dengan nilai tukar yang berlaku pada saat itu dan tunai. Dengan ketentuan yang ditetapkan menunjukkan transaksi jual beli mata uang diperbolehkan (DSN-MUI, 2002).

Rumusan masalah dalam penelitian ini berkembang dari tingkat popularitas penggunaan Bitcoin, kecenderungan fluktuasi yang tinggi mendorong ulasan yang menarik kointegrasi, kausalitas yang terjadi pada Bitcoin. Tujuan penelitian adalah (1) untuk menguji kointegrasi Bitcoin terhadap nilai tukar Rupiah, (2) menguji 
kausalitas Bitcoin terhadap nilai tukar Rupiah sehingga dapat diketahui hubungan yang terbentuk antara Bitcoin dan Rupiah, (3) untuk mengetahui pandangan Islam mengenai transaksi Bitcoin. Sehingga isu yang diangkat berkaitan dengan Bitcoin, nilai tukar Rupiah dan cara pandangan Islam dalam transaksi Bitcoin. Hal yang memiliki signifikansi besar untuk diteliti sehingga menambah pengayaan teori penelitian serta memberi sumbangsih lebih dalam bidang ekonomi serta Islam.

\section{LANDASAN TEORI}

Nilai tukar menurut Nopirin (2014) merupakan nilai dari pertukaran mata uang yang berlainan sehingga mendapatkan kesetimpalan nilai atau harga yang ada di selasela kedua mata uang. Secara ringkas menurut Abimanyu (2004) nilai tukar adalah harga satu mata uang local terhadap mata uang asing. Harga dari mata ditentukan oleh penawaran dan permintaan yang terjadi melalui mekanisme pasar valuta asing Menurut Sukirno (2016), nilai tukar valuta asing memiliki perubahan pada: (1) apresiasi yaitu kenaikan nilai mata uang suatu negara terhadap mata uang negara lain, (2) depresiasi yaitu penurunan nilai mata uang suatu negara terhadap negara lain, (3) stabilitas mata uang ditentukan dari titik keseimbangan antara permintaan dan penawaran suatu mata uang.

Konsep digital signature yang dimiliki Bitcoin memungkinkan untuk verifikasi secara tepat, cepat dan tanpa adanya orang ketiga yang dapat melakukan verifikasi, hal ini menjadi pelengkap yang mumpuni bagi Bitcoin yang memiliki dasar konsep sistem decentralized authority transaction (Nakamoto, 2008). Bitcoin merupakan mata uang virtual hasil dari sistem kriptografi dengan jaringan blockchain peer-topeer desentralisasi pertama, dimana setiap blok memberikan informasi transaksi yang dapat dikontrol pengguna transaksi dengan kapitalisasi pasar bitcoin yang menduduki peringkat pertama yaitu 49\% (Bitcoin.org, 2018). Apabila Bitcoin dikaitkan dengan Al-Sharf maka hubungan nya berlaku permintaan dan penawaran mata uang untuk ditukarkan dengan mata uang jenis lain secara tunai (Mardani, 2013).

Berdasarkan temuan terdahulu berkaitan dengan isu Bitcoin yang berkembang pesat. Dengan bahasan hubungan Bitcoin dengan variabel bebas lain serta pandangan Islam mengenai Bitcoin berada pada penelitian yang terpisah. Erdas dan Caglar (2018) mendapati hubungan kausal negatif terjadi antara Bitcoin dan emas, minyak mentah, dolar AS, Indeks BIST 100 (Borsa Istanbul). Uiterwijk (2013) mendapati hubungan positif jangka panjang antara Dow Jones Index, Euro, dan harga minyak. Atik, dkk. (2015) mendapati hubungan kausalitas satu arah Yen Jepang ke Bitcoin. Bouoiyour dan Selmi (2015) mendapati hubungan negatif jangka panjang nilai tukar Bitcoin. Szetela, dkk. (2018) mendapati hubungan negatif antara Bitcoin dan nilai tukar negara lain. Naufal (2016) menguraikan kebolehan penggunaan cryptocurrency untuk ditransaksikan dengan tidak menyalahi aturan agama asal tidak berlebihan. Agustiar (2018) Menerangkan menunjukan tingkat kesiapan untuk membentuk serikat mata uang bagi Negara islam justru lebih kuat jika dipakai mata uang komoditi (emas) dibandingkan mata uang fiat. Nurhisam (2017) Menegaskan penggunaan Bitcoin yang dikatakan syubhat dengan ketentuan yang tidak sesuai dengan aturan syariah.

Penelitian ini berbeda dengan penelitian terdahulu sebelumnya serta penelitian ini memiliki nilai kebaruan dalam hal berupa: (1) objek penelitian Bitcoin dan nilai tukar Rupiah (2) penelitian menerangkan hubungan kointegrasi dan kausalitas yang sebelumnya tidak ditemukan pada peneliti terdahulu (3) tinjauan yang dilakukan 
tidak serta merta Bitcoin secara konvensional namun dalam pandangan Islam yang merujuk pada ketentuan-ketentuan syariah.

\section{METODE PENELITIAN}

Penelitian ini menggunakan metode deskriptif kuantitatif dan analitis. Data time series diperoleh dari situs Coinmarketcap.com (nilai tukar Bitcoin) dan Id.inevsting (nilai tukar Rupiah) berupa data mingguan dalam kurun waktu november 2013 - desember 2019 dengan jumlah 303 observasi yang telah dinormalkan. Penelitian ini menggunakan Bitcoin sebagai independen variabel (X): Data nilai tukar Bitcoin merupakan tingkat harga yang telah disepakati untuk mendapatkan 1 Bitcoin (BTC), satuan dalam USD. Sedangkan variabel dependen nya adalah nilai tukar Rupiah (Y): Data nilai tukar Rupiah merupakan tingkat harga yang disepakati bagi mata uang negara bersangkutan dengan lainnya, sehingga dapat terjadi penggantian nilai yang sesuai dari suatu mata uang, satuan dalam USD.

\section{Model}

Pengujian awal adalah untuk mendeteksi stasioner data dan sejumlah kriteria dalam asumsi klasik. Uji stasioneritas dilakukan untuk melihat apakah data itu stasioner atau non stasioner. Suatu data dikatakan stasioner jika rata-rata (mean), varian, dan kovarian pada setiap lag adalah tetap sama pada setiap waktu (Rohmana, 2010). Dalam pengujian stasioner data, maka perlu diketahui panjang lag optimum, jika data tidak stasioner pada level.

Penulis menggunakan uji autokolerasi bertujuan menguji apakah dalam model regresi linear ada kolerasi antara kesalahan pengganggu pada periode $t$ dengan kesalahan pengganggu pada periode t-1. Jika terjadi autokolerasi maka dinamakan ada problem autokolerasi (Ghozali, 2016). Kedua adalah melakukan pengujian uji heteroskedastisitas yaitu untuk mengetahui apakah dalam model regresi terjadi ketidaksamaan variance dari residual satu pengamatan ke pengamatan yang lain. Jika variance dari residual satu pengamatan ke pengamatan lain tetap, maka disebut homoskedastisitas dan jika berbeda disebut heteroskedastisitas.

Model kointegrasi menggunakan uji kointegrasi Johansen yang dikembangkan oleh Johansen untuk menentukan kointegrasi sejumlah variabel (Widarjono, 2007). Uji kointegrasi ini hanya bisa dilakukan saat data yang digunakan dalam penelitian berintegrasi pada derajat yang sama. Metode statistik yang digunakan yaitu sebagai berikut:

1. The diagonal elements and trace test (uji element diaonal dan uji jejak). Uji jejak juga dikenal dengan trajectory test, uji statistiknya adalah:

$$
\lambda_{\text {trance }}(r)=-T \sum_{i=r+1}^{n} \ln \left(1-\dot{\hat{\lambda}}_{1}\right)
$$

$H_{0}$ : $\operatorname{rank}(\Pi) \leq r$, bagian $r$ kelompok dari vektor kointegrasi, $H_{1}$ : rank $(\Pi)>r ; \Pi$ adalah jumlah kelompok matriks vektor independen, yaitu jumlah nilai Eigen yang berbeda dari 0; $\mathrm{T}$ adalah jumlah sampel; $\mathrm{r}$ adalah jumlah kelompok vektor yang terkointegrasi; $\hat{\lambda}_{1}$ adalah nilai estimasi untuk nilai Eigen i ; $\mathrm{n}$ adalah jumlah yang dihasilkan dari nilai-nilai Eigen yang memenuhi distribusi chi-square dan under examination.

2. The maximum Eigen value test. Uji statistiknya adalah:

$$
\lambda_{\max }(r, r+1)=-T \ln \left(1-\hat{\lambda}_{r+1} \cdot\right.
$$


$H_{0}: \operatorname{rank}(\Pi)=r$, dimana $r$ kelompok dari vektor kointegrasi, $H_{1}: \operatorname{rank}(\Pi)=r+1$; $\mathrm{T}$ adalah jumlah sampel; $\mathrm{r}$ adalah jumlah kelompok vektor yang terkointegrasi; $\hat{\lambda}_{i}$ adalah nilai estimasi untuk nilai Eigen i yang memenuhi distribusi chi-square dan dibawah hasil uji.

Dengan hipotesis sebagai berikut:

$\mathrm{H}_{0}$ : Tidak terdapat hubungan jangka panjang antara variabel Bitcoin dan variabel nilai tukar Rupiah.

$\mathrm{H}_{1}$ : Terdapat hubungan jangka panjang antara variabel Bitcoin dan variabel nilai tukar Rupiah.

Pengambilan keputusan diambil dengan kriteria sebagai berikut: (signifikansi pada taraf 5\%)

Jika nilai trace statistic $>$ nilai critical value maka H0 ditolak

Jika nilai trace statistic < nilai critical value maka H0 diterima

Sedangkan untuk menguji kausalitas menggunakan Uji kausalitas Engel \& Granger (1987). Tujuan kausalitas Granger adalah meneliti apakah A mendahului B, ataukah B mendahului A, ataukah hubungan antara A dan B timbal balik.

1. Jika $\Sigma a j \neq 0$ dan $\Sigma$ bj $=0$, maka terdapat kausalitas satu arah dari variabel Bitcoin (X) terhadap variabel nilai tukar Rupiah (Y).

2. Jika $\Sigma$ aj $=0$ dan $\Sigma b j \neq 0$, maka terdapat kausalitas satu arah dari variabel nilai tukar Rupiah (Y) terhadap variabel Bitcoin (X).

3. Jika $\Sigma$ aj $=0$ dan $\Sigma$ bj $=0$, maka tidak terdapat hubungan kausalitas baik antara variabel nilai tukar rupiah (Y) terhadap variabel Bitcoin (X) maupun antara variabel Bitcoin $(\mathrm{X})$ terhadap variabel nilai tukar Rupiah $(\mathrm{Y})$.

4. Jika $\Sigma a j \neq 0$ dan $\Sigma b j \neq 0$, maka terdapat kausalitas dua arah baik antara variabel nilai tukar rupiah (Y) terhadap variabel Bitcoin (X) maupun antara variabel Bitcoin (X) terhadap variabel nilai tukar Rupiah (Y).

\section{Analisis Regresi Linier (Time Series)}

Analisis regresi menggunakan regresi linear times series. Penulis menggunakan metode ARCH-GARCH untuk mendapatkan hubungan antara variabel terikat dan variabel bebas tunggal. Regresi linier sederhana time series: (Priyatno, 2008), sebagai berikut:

Keterangan:

$$
I D R_{t}=\beta_{0}+\beta_{1} B T C_{t}+e_{t}
$$

IDR : Nilai tukar Rupiah

$\boldsymbol{t} \quad$ : Periode

$\boldsymbol{\beta}_{\mathbf{0}} \quad$ : Intersep atau nilai Y saat $\mathrm{X}=0$

$\boldsymbol{\beta}_{\mathbf{1}}$ : Parameter dari $B T C_{t}$

$\boldsymbol{B T C}_{\boldsymbol{t}}$ : Nilai tukar Bitcoin

$\boldsymbol{e}_{\boldsymbol{t}} \quad$ : Error term atau derajat kesalahan

Pemilihan model terbaik pada penelitian adalah Metode ARCH-GARCH dengan signifikansi parameter yang sesuai dengan model. Selanjutnya pengujian signifikan parameter yang dilakukan untuk mengetahui signifikan tidaknya variabel independen secara individual dalam menerangkan variasi variabel dependen (Ghozali, 2016). Uji z digunakan untuk mengetahui seberapa jauh pengaruh variabel Bitcoin secara individual dalam menerangkan variasi variabel nilai tukar Rupiah. 


\section{HASIL DAN PEMBAHASAN}

\section{Uji Stationeritas}

Tabel 1: Hasil Uji Root Pada Tingkat First Difference

\begin{tabular}{|c|c|c|c|}
\hline \multirow[t]{3}{*}{ Variabel } & & & \multirow[t]{3}{*}{ Keterangan } \\
\hline & \multicolumn{2}{|c|}{ Augmented Dickey-Fuller test statistic } & \\
\hline & t-statistik & Prob & \\
\hline IDR & -15.74968 & 0.0000 & Stasioner \\
\hline BTC & -17.83325 & 0.0000 & Stasioner \\
\hline
\end{tabular}

Berdasarkan dari hasil uji stationer pada tabel 4 dengan tingkat first difference, maka dapat diketahui bahwa variabel yang ada pada penelitian ini lolos pada uji tingkat first difference dengan menggunakan Augmented Dickey-Fuller test statistic. Hal ini dibuktikan dengan nilai probabilitas $<0,05$.

Tabel 2: Panjang Lag Optimum

\begin{tabular}{ccccccc}
\hline Lag & LogL & LR & FPE & AIC & SC & HQ \\
\hline 0 & - & na & 1.168215 & 5.831231 & 5.856227 & 5.841240 \\
& 858.1065 & & & & & \\
\hline 1 & 320.8594 & 2333.953 & 0.000405 & -2.134640 & - & - \\
& & & & & $2.059651^{*}$ & $2.104613^{*}$ \\
\hline 2 & 323.4119 & 5.018467 & 0.000409 & -2.124827 & -1.999844 & -2.074781 \\
\hline 3 & 325.9352 & 4.926892 & 0.000414 & -2.114815 & -1.939840 & -2.044751 \\
\hline 4 & 327.6934 & 3.409132 & 0.000420 & -2.099617 & -1.874649 & -2.009534 \\
\hline 5 & 332.2463 & 8.766206 & 0.000418 & -2.103365 & -1.828404 & -1.993264 \\
\hline 6 & 341.3965 & $17.49397^{*}$ & $0.000404^{*}$ & - & -1.813328 & -2.008162 \\
& & & & $2.138282^{*}$ & & \\
\hline 7 & 342.8253 & 2.712148 & 0.000411 & -2.120849 & -1.745903 & -1.970711 \\
\hline 8 & 345.5329 & 5.103163 & 0.000415 & -2.112087 & -1.687148 & -1.941931 \\
\hline \multicolumn{7}{l}{ Sumber: Hasil Pengolahan Uji EViews 10 (Data diolah, 2020) }
\end{tabular}

Dengan hasil yang demikian menunjukkan bahwa; untuk melakukan uji selanjutnya dapat digunakan pada lag optimum 6 .

\section{Uji Kointegrasi}

Tabel 3: Uji Kointegrasi Johansen berdasarkan Trace Statistic

\begin{tabular}{cccccc}
\hline Variabel & $\begin{array}{c}\text { Hypothesized } \\
\text { No. of CE(s) }\end{array}$ & Eigenvalue & $\begin{array}{c}\text { Trace } \\
\text { Statistic }\end{array}$ & $\begin{array}{c}0.05 \\
\text { Critical } \\
\text { Value }\end{array}$ & Prob. \\
\hline BTC - IDR & None & 0.025162 & 9.249181 & 15.49471 & 0.3428 \\
& At most 1 & 0.005538 & 1.654865 & 3.841466 & 0.1983 \\
\cline { 2 - 6 } & & & & \\
\hline \multicolumn{2}{l}{ Sumber: Hasil Pengolahan Uji EViews 10 (Data diolah, 2020) } & & & \\
\end{tabular}

Tabel 4: Uji Kointegrasi Johansen berdasarkan Rank Test (Maximum Eigenvalue)

\begin{tabular}{cccccc} 
Variabel & $\begin{array}{c}\text { Hypothesized } \\
\text { No. of CE(s) }\end{array}$ & Eigenvalue & $\begin{array}{c}\text { Max-Eigen } \\
\text { Statistic }\end{array}$ & $\begin{array}{c}0.05 \\
\text { Critical } \\
\text { Value }\end{array}$ & Prob. \\
\hline BTC - IDR & None & 0.025162 & 7.594317 & 14.26460 & 0.4214
\end{tabular}




$\begin{array}{lllll}\text { At most } 1 & 0.005538 & 1.654865 & 3.841466 & 0.1983\end{array}$

Sumber: Hasil Pengolahan Uji EViews 10 (Data diolah, 2020)

Berdasarkan uji kointegrasi diatas menunjukkan hasil tidak adanya keseimbangan jangka panjang, berdasarkan uji kointegrasi seluruh variabel dengan metode Johansen nilai Trace Statistic dan nilai Maximum-Eigenvalue Statistic.

\section{Uji Kausalitas Engel Granger}

Tabel 5: Uji Kausalitas Engel Granger

\begin{tabular}{lccc}
\hline Null Hypothesis: & Obs & $\begin{array}{c}\text { F- } \\
\text { Statistic }\end{array}$ & Prob. \\
\hline IDR does not Granger Cause BTC & 297 & 3.19565 & 0.0047 \\
\cline { 3 - 4 } BTC does not Granger Cause IDR & & 1.13782 & 0.3404 \\
\hline Sumber: Hasil Pengolahan Uji EViews 10 (Data diolah, 2020) & & & \\
Signifikansi pada taraf uji 10\% & & &
\end{tabular}

Dapat disimpulkan bahwa terjadi hubungan kausalitas positif satu arah antara variabel nilai tukar Bitcoin terhadap nilai tukar Rupiah dengan penentuan panjang lag 6.

\section{Analisis Regresi Linier (Time Series)}

Perhitungan analisis regresi linier sederhana dengan menggunakan metode ARCH-GARCH mendapatkan hasil estimasi perhitungan sebagai berikut:

Tabel 6: Hasil Uji Analisis Regresi Linier (Time Series)

\begin{tabular}{lcccc}
\hline Variable & Coefficient & Std. Error & Z-Statistic & Prob. \\
\hline C & -0.013369 & 0.009236 & -1.447570 & 0.1477 \\
\hline BTC & -0.216510 & 0.009349 & -23.15826 & 0.0000 \\
\hline R-square & 0.124164 & & \\
\hline Adjusted R-adjusted & 0.121254 & & \\
\hline \multicolumn{2}{l}{ Sumber: Hasil Pengolahan Uji EViews 10 (Data diolah, 2020) }
\end{tabular}

positif terhadap nilai tukar Rupiah. Regresi time series menunjukkan hasil, apabila variabel Bitcoin mengalami peningkatan maka terjadi penurunan $0.216 \%$ terhadap variabel nilai tukar rupiah dengan besaran $\mathrm{R}^{2} 0.124164$ mengindikasi lemahnya hubungan kedua variabel serta dengan nilai z-Statistic -23.15826 maka dikatakan Bitcoin signifikan memiliki pengaruh Hasil regresi menjelaskan pengaruh variabel independen terhadap variabel dependen, dimana ketika variabel independen yaitu nilai tukar Bitcoin mengalami peningkatan 1\%, maka nilai tukar Rupiah mengalami penurunan $0.216 \%$. Nilai $\mathrm{R}^{2}$ mengindikasikan bahwa lemahnya hubungan nilai tukar Bitcoin terhadap nilai tukar Rupiah, artinya variabel independen yaitu nilai tukar Bitcoin dapat menerangkan variabel dependen yaitu nilai tukar Rupiah sebesar $12 \%$ rata-rata variabel terikat dijelaskan oleh rata-rata variabel bebas. Sedangkan persentase sisanya $88 \%$ diterangkan oleh variabel lain. Dilakukan uji signifikan nilai probability lebih kecil dari level of significance $(\alpha=0,05)$ dengan nilai z statistik menunjukkan angka -23.15826. Maka dapat dikatakan bahwa hipotesis nilai tukar Bitcoin memiliki pengaruh yang signifikan terhadap nilai tukar Rupiah.

Berdasarkan hasil penelitian yang telah dilakukan, maka dapat dilihat kedua variabel dalam penelitian ini menerangkan tidak terdapat kointegrasi atau tidak memiliki hubungan jangka panjang namun terdapat hubungan kausalitas satu arah atau hubungan timbal balik satu arah yang terjadi antara kedua variabel, dimana hasil 
menunjukkan terjadi pengaruh signifikan variabel nilai tukar Bitcoin terhadap nilai tukar Rupiah. Dengan demikian, hasil uji dalam penelitian ini tidak sesuai dengan asumsi hipotesis, yaitu tidak terdapat kointegrasi atau indikasi keterkaitan jangka panjang: nilai tukar Bitcoin terhadap nilai tukar Rupiah serta terdapat indikasi keterkaitan kausalitas satu arah yang terjadi antara nilai tukar Bitcoin terhadap nilai tukar Rupiah serta tidak menunjukkan adanya hubungan kausalitas yang terjadi antara nilai tukar Rupiah terhadap nilai tukar Bitcoin.

\section{Pandangan Islam mengenai Bitcoin}

Bitcoin digunakan sebagai mata uang namun tidak memiliki bentuk fisik sehingga dikatakan sebagai uang elektronik. Dikaitkan dengan ketentuan syariat islam yang memperbolehkan pertukaran mata uang seperti hal nya yang berlaku pada transaksi al-sharf, tentu saja dengan menaati rukun dan syarat yang berlaku, yang disebutkan dan tertera pada al-quran, hadis, qiyas dan ijma ulama. Dasar hukum yang menjadi landasan diperbolehkannya al-sharf, firman Allah dalam QS. An-Nisa ayat 29: "Wahai orang-orang yang beriman! Janganlah kamu saling memakan harta sesamamu dengan jalan yang batil (tidak benar), kecuali dalam perdagangan yang berlaku atas dasar suka sama suka di antara kamu. Dan janganlah kamu membunuh dirimu. Sungguh, Allah Maha Penyayang kepadamu.

Firman Allah dalam QS. Al-Baqarah ayat 275: "Orang-orang yang memakan riba tidak dapat berdiri, melainkan seperti berdirinya orang yang kemasukan setan karena gila. Yang demikian itu karena mereka berkata bahwa jual beli sama dengan riba. Padahal, Allah telah menghalalkan jual-beli dan mengharamkan riba. Barang siapa mendapat peringatan dari Tuhannya, lalu dia berhenti, maka apa yang telah diperolehnya dahulu menjadi miliknya dan urusannya (terserah) kepada Allah. Barang siapa mengulangi, maka mereka itu penghuni neraka, mereka kekal di dalamnya.

Berdasarkan ayat diatas, dijadikan pedoman umat islam untuk melakukan transaksi al-sharf dan Bitcoin tergolong dalam al-sharf. Di mana terjadi kesepakatan untuk menukar mata uang rupiah dengan dolar maupun sebaliknya. Tentu saja dengan media yang berbeda, Bitcoin diakses dengan kecanggihan teknologi masa kini yang terhubung dengan internet sehingga tidak memiliki bentuk fisik layaknya uang kertas dan koin. Dengan menelaah dari ketentuan syariat yang sesuai dengan al-sharf dikaitkan pada Bitcoin. Maka dapat menimbang kemadharatan yang ditimbulkan dari kegiatan transaksi yang dilakukan. Untuk itu menurut rukun dan syarat al-sharf yang pertama, penjual (al-bay) bertindak sebagai pelaku akad dan pembeli (al-mushtary). Kedua, al-sharf (valuta) bertindak sebagai objek akad dan nilai tukar atau exchange rate (si'rual-sharf). Ketiga, shighat. Dalam hal ini transaksi Bitcoin tidak melakukan shighat seperti umumnya karena pada transaksi Bitcoin hanya dilakukan dengan meng-klik fitur yang tersedia pada akun masing-masing pengguna (Ascarya, 2012). Berkaitan dengan transaksi serah terima Bitcoin terjadi jika al'mushtary dan al-bay telah sepakat dan sesuai dengan ketentuan harga diantaranya. Namun ketika al-bay memasang harga tidak sesuai dengan harga yang diorder akan menyebabkan tertundanya serah terima, hal ini menunjukkan tidak terpenuhinya syarat al-sharf yang seharusnya dilakukan secara kontan. Malik dan Naf'I dari Abu Sa'id al-Khudri r.a meriwayatkan dalam hadis bahwa Rasulullah bersabda: "Janganlah kalian menjual emas dengan emas kecuali sama beratnya dan perak dengan perak kecuali sama beratnya, sebagian tidak dilebihkan atas sebagian yang lain. Dan janganlah 
kalian menjual dari jenis tersebut antara yang belum ada dengan yang tunai (menjualnya secara tempo)."

Berdasarkan kesepakatan yang disyaratkan ulama, maka transaksi permintaan dan pembelian mata uang harus secara tunai namun terdapat pembedaan waktu batas diantara para ulama. Menurut Abu Hanifah dan Syafi (dalam kitab Sahih Muslim bi Syarh an-Nawawi): mengatakan mata uang dapat dilakukan jual beli asalkan tunai serta pihak-pihak yang melakukan jual beli belum berpisah. Sedangkan menurut Maliki (dalam kitab Sahih Muslim bi Syarh an-Nawawi), jika penerimaan yang terlambat diserahkan pada majelis menyebabkan batalnya jual walaupun pihak penjual dan pembeli belum berpisah.

Pembahasan transaksi Bitcoin menurut ulama kontemporer berdasarkan kepada firman Allah dalam QS. al-Maidah ayat 90: “Wahai orang-orang yang beriman! Sesungguhnya minuman keras, berjudi, (berkurban untuk) berhala, dan mengundi nasib dengan anak panah adalah perbuatan keji dan termasuk perbuatan setan. Maka jauhilah (perbuatan-perbuatan) itu agar kamu beruntung. Menurut Karim (2010) maysir adalah sebuah permainan, pihak pertama menanggung kerugian atas pihak lain akibat permainan itu. Gharar termasuk bagian maysir karena adanya suatu perkara tidak jelas yang bersifat mendatangkan profit saja atau high speculation (Karim, 2010). Berangkat dari kata gharar terdapat hadis yang diterima oleh Abu Hurairah sebagai berikut. 'An Abi Hurairah ra qala, naha Rasulullahi SAW 'an ba'i alhashat, wa 'an ba'I al-gharar (HR.Muslim, 1993:139). Sebagaimana tertuang di dalam kitab Shahih Muslim. Abi Hurairah berkata, sesungguhnya Rasulullah SAW melarang jual beli al-hashat yakni dengan cara melempar, dan jual beli al-gharar, mengandung unsur ketidakjelasan. Hadis kedua dari Ibn Masud. 'An Abi Masud, anna nabiyya Shallallahu alaihi wa sallam qala la tasytaru al-samaka fi al-mai fa innahu gharar.' Hadis ini diriwayatkan oleh Imam Ahmad artinya, dari Ibn Mas'ud, sesungguhnya Nabi SAW bersabda, janganlah membeli ikan di dalam air karena sesungguhnya hal itu adalah gharar.

Berkaitan dengan ayat serta hadis yang telah dijelaskan, memiliki kesamaan dengan transaksi Bitcoin. Nilai impor dan ekspor tidak memiliki kaitan naik dan turun dalam pergerakan nilai tukar Bitcoin seperti halnya nilai tukar rupiah namun terjadi melalui mekanisme permintaan dan penawaran. Fluktuasi Bitcoin cenderung berubah-ubah dengan cepat menandakan tidak ada dasar aset (underlaying asset), hal ini menjadikan Bitcoin dapat naik secara pesat dan menukik turun secara tajam. sangat cepat dan dapat turun menukik tajam. Oleh karena itu, seperti terjadi pertaruhan pada bisnis Bitcoin. Ulama kerajaan Arab Saudi, Syaikh Assim al-Hakeem tidak mengizinkan transaksi Bitcoin yang dianggap tidak memiliki kejelasan pemilik sehingga mendorong tindakan pencucian uang maupun tindakan lainnya (Assimalhakeem, 2017).

\section{KESIMPULAN}

Penelitian ini bertujuan untuk mengetahui kointegrasi, kausalitas dan pengaruh antara Bitcoin dan nilai tukar Rupiah. Metode uji regresi linier sederhana dengan metode ARCH-GARCH, Kointegrasi Johansen, dan Kausalitas Engel Granger. Data Bitcoin dan nilai tukar menggunakan data mingguan selama enam tahun (2013-2019). Penelitian ini mendapatkan Bitcoin tidak memiliki kointegrasi jangka panjang pada nilai tukar Rupiah. Hubungan kausalitas berbentuk pola searah yang terjadi pada Bitcoin terhadap nilai tukar Rupiah. Bitcoin memiliki pengaruh terhadap nilai tukar Rupiah. pen antara variabel Bitcoin dan variabel nilai tukar Rupiah. 
Transaksi Bitcoin dalam pandangan Islam, jika digunakan sebagai alat transaksi pembayaran tidak memenuhi salah satu rukun maupun syarat al-sharf hal ini tidak sejalan ketentuan syariat Islam, seharusnya transaksi Bitcoin harus dilakukan secara cash dan tidak terjadi pembatalan setelahnya walaupun terjadi pending order, serta berdasarkan landasan al-quran berikut dengan hadis Rasulullah menyatakan Bitcoin bersifat maysir, batil, dan gharar. Penelitian ini paling tidak telah memperkaya pemahaman kita tentang mata uang baru yang sedang menjadi isu mengemuka. Penulis menyadari bahwa tidaklah mudah memahami Bitcoin dalam konteks transaksi, namun penulis telah mencoba membangun penjelasan ekonometrika untuk melihat arah dan kausalitas nya dengan mata uang Rupiah.

\section{DAFTAR PUSTAKA}

Abimanyu, Y. (2004). Memahami kurs valuta asing. Fakultas Ekonomi, Universitas Indonesia.

Agustiar, M., Djafar, F., \& Afrizal, A. (2017). Construction of an Optimum Currency Area Index Anchored to the Gold Dinar: The Case of Selected Islamic Countries. International Journal of Economics and Financial Issues, 7(3), 51.

Ascarya. (2012). Akad dan Produk Bank Syariah. Jakarta: PT Raja Grafindo Persada.

Assimalhakeem. (2017, Februari 01). Is bitcoin halal in islamic point or vew. Retrieved from assimalhakeem: http://www.assimalhakeem.net/sheikh-is-bitcoin-halalin-islamic-point $=$ or-view/

Atik, M., Köse, Y., Yılmaz, B., \& Sağlam, F. (2015). Kripto para: Bitcoin ve döviz kurları üzerine etkileri. Bartın Üniversitesi II BF Dergisi, 6(11), 247-261.

Bitcoin.org. (2018). Retrieved from https://bitcoin.org/en/.

Bouoiyour, J., \& Selmi, R. (2015). What does Bitcoin look like?. Annals of Economics and Finance, 16(2), 449-492.

Coinmarket. (2019). Cryptocurrency Market Capitalization. Retrieved from https://coinmarket.com/.

DSN-MUI. (2002). Jual Beli Mata Uang (al-Sharf) Nomor: 28/DSN-MUI/III/2002. Jakarta.

Erdas, M. L., \& Caglar, A. E. (2018). Analysis of the relationships between Bitcoin and exchange rate, commodities and global indexes by asymmetric causality test. Eastern Journal of European Studies, 9(2), 27.

Hr. Imam At-Tirmidzi, dari Ubadah bin Shamit. (n.d.).

Karim, A. A. (2010). Bank Islam, Analisis Fiqih dan Keuangan, ed. 3, cet. 3.

Kementerian Agama, R. I. (2012). Al-Qur'an dan Terjemahannya, Jakarta: PT. Sinergi Pustaka Indonesia.

Ly, M. K. M. (2013). Coining bitcoin's Legal-Bits: Examining the regulatory framework for bitcoin and virtual Currencies. Harv. JL \& Tech., 27, 587.

Mardani, D. (2015). Fiqh Ekonomi Syariah: Fiqh Muamalah. Prenada Media.

Nakamoto, S., \& Bitcoin, A. (2008). A peer-to-peer electronic cash system. Bitcoin.URL: https://bitcoin. org/bitcoin. pdf, 4.

Naufal, M. (2016). Cryptocurrency dalam Pandangan Islam. Program Studi Teknik Informatika, Sekolah Teknik Elektro dan Informatika, Institut Teknologi Bandung.

Nopirin. (2014). Pengantar Ilmu Ekonomi Mikro-Makro. Yogyakarta: BPFE-Yogyakarta. 
Nurhisam, L. (2020). Bitcoin dalam kacamata hukum islam. Ar-Raniry, International Journal of Islamic Studies, 4(1), 165-186.

Priyatno, D. (2008). Mandiri belajar SPSS. Yogyakarta: Mediakom.

Ramadhani, M. A. (2015). Pengaruh Produk Domestik Bruto, Nilai Tukar dan Upah Tenaga Kerja Terhadap Pertumbuhan Foreign Direct Investment Sektor Manufaktur Di Indonesia. Jurnal Administrasi Bisnis, 27(2).

Rohmana, Y. (2010). Ekonometrika: Teori dan Aplikasi dengan Eviews. Bandung: Laboratorium Pendidikan Ekonomi dan Koprasi UPI.

Sanjaya, H. Ghozali, I.(2016). Aplikasi Analisis Multivariete dengan Program IBM SPSS 23 (VIII). Semarang: Badan Penerbit Universitas Diponegoro

Sovbetov, Y. (2018). Factors influencing cryptocurrency prices: Evidence from bitcoin, ethereum, dash, litcoin, and monero. Journal of Economics and Financial Analysis, 2(2), 1-27.

Sukirno, S. (2016). Makroekonomi: Teori Pengantar (Ketiga). Jakarta: PT Raja Grafindo Persada.

Szetela, B., Mentel, G., \& Gędek, S. (2016). Dependency analysis between bitcoin and selected global currencies. Dynamic econometric models, 16(1), 133-144.

Uiterwijk, V. (2013). Bitcoin: Het samenstellen van een efficiente markt portfolio met Bitcoin. BSc Economics \& Business, Erasmus School of Economics, Erasmus University Rotterdam.

Widarjono, A. (2007). Inet Aplikasi. Yogyakarta: Ekonisia FE UII. 